\title{
Use of Chitosan for Enhancing the Process of Surface Water Purification in Egypt
}

\author{
Rania S. M. A. Hamdon, Ahmed Salem, Hany G. I. Ahmed, Medhat M. H. ElZahar
}

\begin{abstract}
Natural Organic Matter (NOM) is found in all surface waters. An increase in the amount of NOM over the past 10-20 years has been observed in raw water supply in many areas in Egypt, which has had a significant impact on drinking water treatment. Water scarcity and the increased contamination of drinking water has led to increased doses of coagulants and disinfectants used in water treatment, which has led to increased sludge volume and the production of harmful residual byproducts. In this paper, the results of experiments using an experimental model carried out to investigate improving the removal efficacy of NOM using a natural coagulant, such as chitosan, along with alum, are presented. The results show the use of chitosan is effective in removing NOM and reducing algae and turbidity. In addition, a dose of chitosan added to alum successfully reduced the amount of alum needed in the purification process.
\end{abstract}

Index Terms-Alum, chitosan, coagulation, flocculation, NOM, water purification.

\section{INTRODUCTION}

Water pollution is one of the greatest concerns in developed and underdeveloped countries. The substantial pollution of water bodies is standard of developing countries affected by the maximum serious effects of this resource degradation, the spreading of water-related illnesses [1], [2]. Waterborne illnesses that launch parasitic and diseased microorganisms into water bodies are a result of the lack of expertise and resources to build and maintain a healthy sanitation apparatus [3], [4].

In 2017, about 2.72 billion and 2.38 billion rural residents were still lacking basic drinking water and sanitation services (UNICEF and WHO, 2020) [5]. The vast majority of these people are positioned in rural regions of Africa, South Asia, and East Asia [4]. Around five million lives are lost annually due to the consumption and use of infected water [4]-[6]. Many pollutants can be found in surface water streams, one of them is the natural organic matter (NOM) [7], [8].

Chitosan is a linear copolymer that is produced by deacetylation of chitin, which is the second-most abundant biopolymer in the world after cellulose. Due to its unique

Manuscript received July 11, 2021; revised October 13, 2021. This work was conducted and supported in part by Al-Azhar University, Port Said University, and The National Research center, Egypt.

Rania S. M. A. Hamdon is with Civil Engineering Department, Giza Engineering Institute, El-moneb, Giza, Egypt (e-mail: civ.rania1990@gmail.com).

Ahmed Salem and Hany G. I. Ahmed are with Civil Engineering Department, Faculty of Engineering, Al-Azhar University. Cairo, Egypt (e-mail: ahmedsalemy@azhar.edu.eg, ahmedsalemy@yahoo.com, hanyahmed@azhar.edu.eg).

Medhat El-Zahar is with Civil Engineering Department, Faculty of Engineering, Port Said University, 42523, Port Said, Egypt (e-mail: medhat.alzahar@eng.psu.edu.eg, melzahar@yahoo.com). properties, chitosan is used in many industrial applications [8]. Chitosan has also attracted significant amount of research attention as a promising coagulant and flocculant, owing to its environment friendly properties [8], [9].

\section{A. Natural Organic Matter in Water}

NOM is a complicated organic component of natural surface water [10]. The term Natural Organic Matter refers to a large spectrum of chemical substances that result from natural processes inside the environment, consisting of the decomposition of natural and algal metabolic reactions [11]. Proteins, amino acids, polysaccharides, hemic, and folic acids are all examples of NOM [11]. The presence of NOM poses problems at specific stages in water purification, most notably the formation of poisonous residual byproducts [12], [13].

\section{B. Chitosan As a Coagulant}

Chitosan-based materials have also been recommended in laboratory studies as potentially eco-friendly coagulants and flocculants for water and wastewater treatment because of their natural biological characteristics and biodegradability [14].

Chitosan has been reported to perform well as a coagulant by removing chlorella in algae turbid water, removing turbidity from sea water, and for harvesting microalgae [15], [16]. It has several industrial and commercial utilities, can be recycled, and is an excellent chelating agent for many metals such as arsenic, molybdenum, cadmium, chromium, lead, and cobalt [17]. The use of chitosan as a drinking water coagulant has been the focus of several studies. The chemical modification methods used to prepare chitosan-based flocculants and the impact of auxiliary elements on flocculation properties and mechanisms have been recently reviewed [3], [7].

This study will examine the effectiveness of using chitosan as an environmental-friendly coagulant with and without alum to purify Nile River water in Egypt, focusing on reducing turbidity, TOC, and algae by removing NOM in the stages of water purification [18], [19].

\section{LITERATURE REVIEW}

There is extensive research concerned with water pollution and methods of purifying water using many chemicals. Due to the negative impact of alum on human health, a natural coagulant such as chitosan was highlighted as it does not negatively affect human health [7], [8].

Ample research on water purification by chitosan was carried out as illustrated by Goss and Gorczyca [15]. They recorded that the optimum $\mathrm{pH}$ for coagulation to remove water turbidity was $6.0,5.5$, and 5.5 when using alum, 
chitosan, and ferric chloride, respectively. The aggregate of coagulation at the optimum dose, sedimentation, and paper filtration lowered treated water turbidity by $98.8,96.9$, and 98.9 percentages using alum, chitosan, and ferric chloride as coagulants respectively. They also studied the removal of $\mathrm{BOD}_{5}$ by chitosan, finding it was reduced as the $\mathrm{pH}$ increased. Treated water COD levels were recorded to be better using chitosan rather than alum or ferric chloride as coagulants [13] [14], [15].

\section{Björnar Eikebrokk et al. [1], found that:}

Chitosan is able to remove color and organic carbon from NOM-containing raw water. At doses up to 7.5 $\mathrm{mg} /$ liter-about $80 \%$ of the color is removed. However, the removal of organic carbon is only $35-40 \%$. 2 . The production of sludge solids using chitosan is less than $50 \%$ compared with using alum. 3. Both chitosan and alum are capable of removing biodegradable organic carbon more efficiently than dissolved organic carbon. The dominating molecular weight fractions within the raw waters used were within the range of 5,000-20,000. 4. Although the best TOC removal with algae by chitosan is achieved in the molecular weight range of $5,000-20,000$, TOC is removed to some extent over a huge variety of molecular weight.

\section{EXPERIMENTAL WORK}

Experiments focusing on improving the removal efficacy of NOM using natural coagulants such as chitosan to decrease the negative impacts of using alum were carried out. The performance of chitosan for coagulation was investigated through jar testing using a lab design. A series of three jar tests were performed, using six jars per test (Fig. 1).

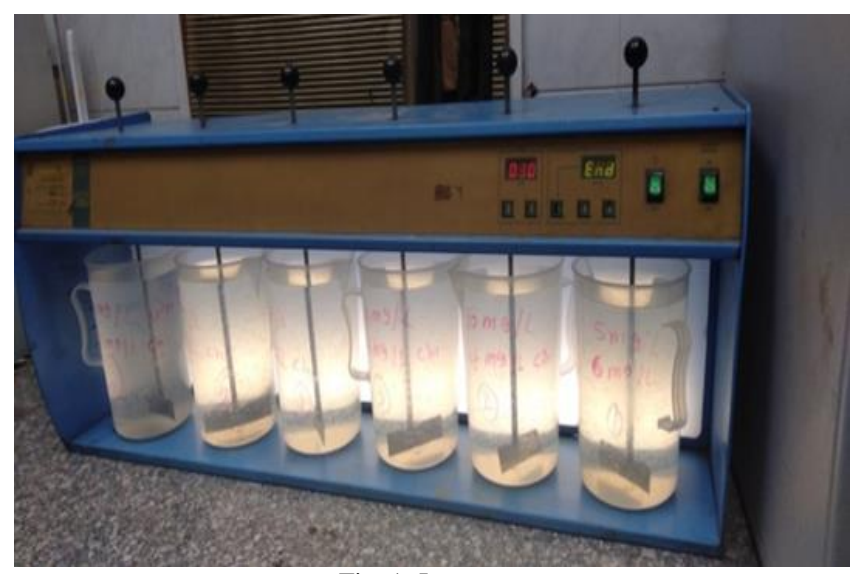

Fig. 1. Jar tester.

The laboratory experiments were divided into three groups, changing the coagulation material in each. The first group used alum as a chemical coagulant, finding the optimal dose to be $23 \mathrm{mg} / \mathrm{L}$, which was the dosage used in Gezeret El-Dahab Water Plant located in Giza (Fig. 2). In the second group of the experiments, the natural coagulant chitosan was used, finding the optimum dose of $8 \mathrm{mg} / \mathrm{L}$. The third group of the experiments used a mixture of the two coagulants chitosan and alum, finding the optimum doses to be 5 and $15 \mathrm{mg} / \mathrm{L}$ respectively [8], [18], [19].

\section{A. Water Samples}

The water samples were taken from the Nile River at
Gezeret El-Dahab Water Plant located in Giza, Egypt, shown in Fig. 2. This location was selected because this plant serves a huge population and has a large amount of NOM. Three water samples were taken from the plant location. Each sample volume was around 12 liters. Jar tester was used to record the optimum dose of each coagulant used. The coagulants used were alum only (current coagulant used), chitosan only, and chitosan mixed with alum. An experimental model was set up consisting of mixing, sedimentation, and filtration to purify the water samples, Fig. 3 .

\section{B. Water Characteristics}

The raw water characteristics are shown in Table I.

TABLE I: RAW WATER CHARACTERISTICS

\begin{tabular}{cc}
\hline \hline RAW WATER CHARACTERISTICS & VALUE \\
\hline PH & 8.00 \\
\hline TDS MG/L & 231 \\
\hline DO MG/L & 6.26 \\
\hline SALINITY $\Delta$ & 0.00 \\
\hline CONDUCTIVITY US/CM & 360 \\
\hline TEMPERATURE C & 25.9 \\
\hline TOC PPM & 6 \\
\hline COD PPM & 18.18 \\
\hline BOD PPM & 16.20 \\
\hline TURBIDITY NTU & 4.5 \\
\hline \hline TOTAL ALGAE UNIT/ML & 4000 \\
\hline CACO 3 MG/L & 138 \\
\hline
\end{tabular}

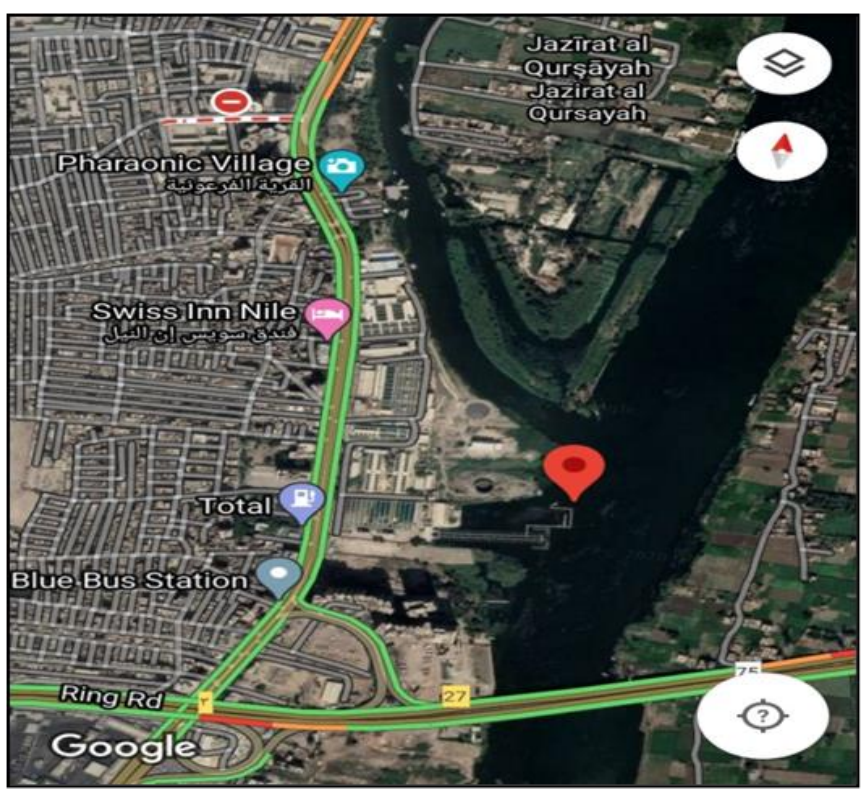

Fig. 2. Intake location (Google map image).

\section{Experiments}

Each group of experiments used different doses of coagulant. The first group used alum in doses of 19, 21, 23, 25, 27 and $29 \mathrm{mg} / \mathrm{L}$. The second group added chitosan doses in doses of 2, 4, 6, 8, 10, and $12 \mathrm{mg} / \mathrm{L}$. The third group added a mixture of alum and chitosan at doses of 10/4, 20/4, 10/5, $15 / 5,10 / 6$, and $5 / 6 \mathrm{mg} / \mathrm{L}$ respectively. A chlorine solution with a dose $7 \mathrm{mg} / \mathrm{liter}$ was added to all experiments. Finally, all experiments were carried out again without adding chlorine to compare the results [20].

The experimental laboratory model consisted of two stages: mixing/sedimentation stage and filtration stage. In the first stage, raw water was mixed with coagulant to produce flocks to settle. In the second stage, filtration was used to complete 
water purification, as shown in Fig. 4 [20], [21].

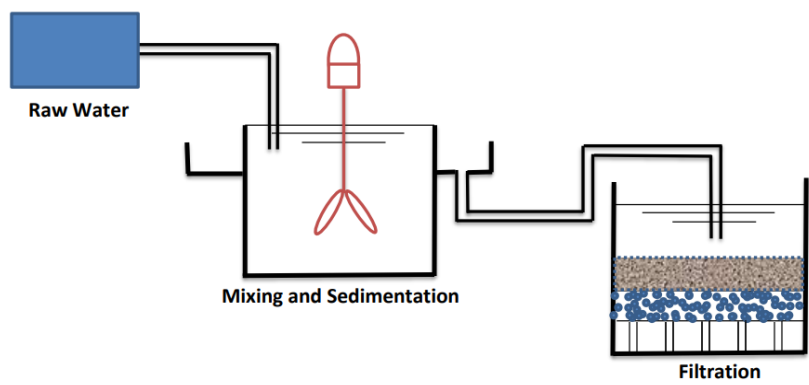

Fig. 3. Experimental model setup [13], [22], [23].

The typical run of one experiment was as follows: -A flash mixing was executed in jar beaker with mixing speed 130rpm for two minutes, then, gentle mixing was used with speed 30rpm for 20 minutes, and then paddles stopped and sedimentation of solids occurred within four minutes. Water was filtered for about 25 minutes using the sand filter mentioned in the filtration stage below. The water samples were measured before mixing and after filtration for the following: turbidity, conductivity, $\mathrm{pH}$, TDS, DO, salinity, conductivity us/cm, $\mathrm{BOD}_{5}, \mathrm{COD}, \mathrm{TOC}$ and temperature ${ }^{\circ} \mathrm{C}$. The initial value of turbidity was almost the same for all samples because experiments were done in the same month.

It was noticed that in the group using chitosan, the flocks were heavy and settled down easily. But, in the group using alum, the formed flocks were light, and part of these flocks did not settle down.

The experimental model was used to simulate the water treatment plant through several variables: [24], [25]

1) Appropriate doses of coagulants used, i.e., alum, chitosan, and alum/chitosan mixture.

2) Sedimentation time which is calculated by Sedimentation time $=$ Sedimentation tank volume/flow rate, i.e., $\mathrm{T}=(\mathrm{W} * \mathrm{H} * \mathrm{~L}) / \mathrm{Q}=\mathrm{V} / \mathrm{Q}$.

3) Filtration process which will be designed in next section according to according to SDI laboratory as shown in Table II [26].

\section{EXPERIMENTAL STAGES}

\section{A. Coagulation/Sedimentation Stage}

In this stage, we added the coagulants alum, chitosan, and alum/chitosan to the raw water at the doses mentioned above. In each stage, the jar test was used to record the optimum coagulant dose. The optimum dose recorded was 23,8 , and $15 / 5 \mathrm{mg} / \mathrm{L}$ for alum, chitosan, and alum/chitosan, respectively. Furthermore, pH, turbidity, algae, BOD5, COD, and TOC were measured or determined. The results were summarized in Tables III, IV, and V and in Figs. 5-16.

The goal of this stage was to minimize the time of sedimentation and to improve the removal efficacy of NOM using chitosan alone or mixed with alum. These merits can result in operation improvement by increasing the capacity of the plant and design improvement by decreasing the size of tanks. These merits could save time for the purification process with better quality of purified water. For example, if $10 \mathrm{~cm}$ of sediment occurred in 60 seconds using alum, 40 seconds would be enough to complete sedimentation using chitosan. Thus, the use of chitosan can increase the efficiency of the water purification process.

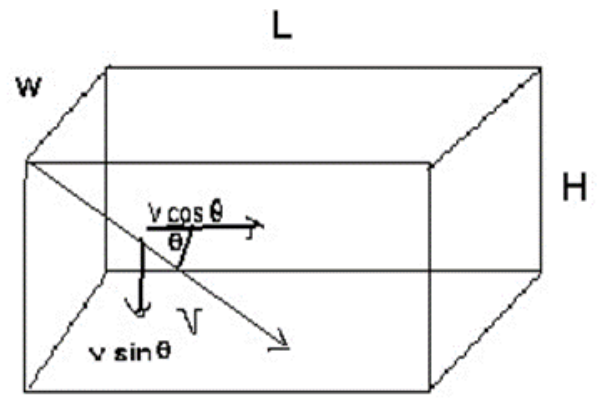

Fig. 4. Sedimentation kinetics.

\section{B. Filtration Stage}

In this stage, a sand filter was designed to purify water after decreasing turbidity in the first stage. The sand filter consists of a circular box $5 \mathrm{~cm}$ in diameter. The filter media consist of an upper layer of $25 \mathrm{~cm}$ thickness of clean, granulated and homogeneous sand. The sand particles diameter is $1.7-2.0 \mathrm{~mm}$. Under that, there is a layer of clean and spherical gravel. The thickness of the gravel layer is 15 $\mathrm{cm}$, made up of an upper part of $5 \mathrm{~cm}$ thickness with gravel diameter equal to 2-6 $\mathrm{mm}$, and the lower gravel layer with a thickness of $10 \mathrm{~cm}$ and gravel diameter equal to $5-15 \mathrm{~mm}$.

\section{Filtration Process Design}

Consider the productivity flow rate equals $0.002 \mathrm{~m}^{3} /$ hour, equivalent to $0.0088 \mathrm{gpm}$, referring to Table II, if the effluent turbidity $=2 \mathrm{NTU}$, then the filtration rate should be $6 \mathrm{gpm} / \mathrm{ft}^{2}$. The dimensions of the filter are shown below.

$$
\begin{aligned}
& \mathrm{A}=\frac{1.47 * 10-3}{3.28}=4.48 * 10^{-4} \mathrm{~m}^{2} \\
& \mathrm{D}=0.055 \mathrm{~m} \\
& \mathrm{D}=5 \mathrm{~cm} \\
& \mathrm{~V}=0.9817 \mathrm{Lit} \\
& \mathrm{V}_{\text {sand }}=\frac{2}{3} * 0.9817=0.654 \mathrm{Lit} \\
& \mathrm{V}_{\text {gravel }}=\frac{1}{3} * 0.9817=0.327 \mathrm{Lit} \\
& \mathrm{V}_{\text {sand }}=0.654 * 1.6=1.04 \mathrm{Kg} \\
& \mathrm{V}_{\text {gravel }}=0.52 * 1.6=0.52 \mathrm{Kg}[11,17] .
\end{aligned}
$$

TABLE II: FILTRATION RATE ACCORDING TO SDI LABORATORY

\begin{tabular}{ccc}
\hline \hline $\begin{array}{c}\text { FILTRATION RATE } \\
\left(\mathrm{GPM} / \mathrm{FT}^{2}\right)\end{array}$ & TURBIDITY & NOTES \\
\hline 4 & $10-20$ & HIGH TURBIDITY \\
\hline 5 & $5-10$ & AVERAGE TURBIDITY \\
\hline 6 & $1-5$ & LITTLE TURBIDITY \\
\hline 7 & $<1$ & NON-TURBID \\
\hline \hline
\end{tabular}

\section{MATERIALS AND METHOdS}

Three types of coagulants, which are available in Egypt, were applied. The first one was a chemical coagulant, aluminum sulfate, (alum, $\left.\mathrm{Al}_{2}\left(\mathrm{SO}_{4}\right)_{3} 16 \mathrm{H}_{2} \mathrm{O}\right)$. The second one was the natural coagulant chitosan. The third coagulant used was mixture of alum and chitosan. Chlorine was used in the purification plant for disinfection, i.e., it was important to use chlorine during our experiments to have the same conditions as in the plant. Pre-chlorination was carried out by the same values applied in the water plant, which was $7 \mathrm{mg} / \mathrm{L}$. 
Moreover, the percentage of pollutant removal was recorded as shown in the tables and figures below. The materials used in the experiments were prepared as follows:

\section{A. Chlorine}

Chlorine, used in the water purification process, has an important role in sterilizing water. It is widely available in the market. in a solid form in the form of colorless crystals, which are not used in this form in water purification. Instead, a chlorine solution was prepared by using the hydroxide chloride $65 \%$, which means that the chlorine percentage is $65 \%$ with existing $35 \%$ impurities. The chloride hydroxide was chosen because it contains enough chlorine percentage [13], [14]. Volume to be prepared is one-liter, initial residual chlorine concentration is $0.0 \mathrm{mg} / \mathrm{L}$, final residual chlorine concentration is $100 \mathrm{mg} / \mathrm{L}$. Weight of calcium hypochlorite with $65 \%$ chlorine which was available for use is $0.1538 \mathrm{~g}$.

\section{B. Alum}

Alum is a chemical compound made of alum stone. This stone contains two types of salt, potassium sulfate and hydrothermal aluminum. Alum consists of a mixture of these two salts, dissolving in water or liquid glycerin [23]. Alum could be dissolved in water for a period of 5-10 minutes [24]. There is also potassium and sodium aluminum, used to sterilize and disinfect water treated with a solution concentration of $1 \%$. In order to prepare $1 \%$ of alum solution, i.e., $10 \mathrm{mg} / 1000 \mathrm{ml}$, thus, each liter of this solution contains $10 \mathrm{mg}$ of alum [23], [24].

\section{Chitosan}

Chitosan is a biomaterial, primarily produced from the alkaline deacetylation $(40-50 \% \mathrm{NaOH})$ of chitin where this $\mathrm{N}$-deacetylation is almost never complete. The chitosan is considered as a partially $\mathrm{N}$-deacetylated derivative of chitin [21]. It is an abundant natural biopolymer obtained from the exoskeletons of crustaceans and arthropods which is a non-toxic copolymer consisting of b-(1,4)-2-anaino-2-deoxy-D-glucose units. Glucosamine unit contains a free amino group, and these groups can take on a positive which gives amazing properties of chitosan [21]. These biopolymers offer a wide range of unique applications including bioconversion for the production of value-added food products, preservation of foods from microbial deterioration, formation of biodegradable films, recovery of waste material from food processing discards, purification of water, and clarification and de-acidification of fruit juices [21].

Chitosan exists in the form of solid crystals, and in this case, it cannot react or dissolve in water, so three types of salts were evaluated to dissolve chitosan: chitosan hydrochloride $\mathrm{HCL}$, chitosan acetate $\mathrm{CH}_{3} \mathrm{COO}$, and chitosan lactate $\mathrm{OH} \mathrm{CO} \mathrm{CH}_{3} \mathrm{CH}$.

Chitosan acetate was chosen because it was the fastest of the three salts in dissolving chitosan with a dissolution time of 15 minutes. After dissolving chitosan, it is mixed with water to be ready for reaction and use for water purification.

The choice of dissolving chitosan in acetate $\mathrm{CH}_{3} \mathrm{COO}$ for a period of 30 minutes was chosen based on previous studies of chemically different treated chitosan, in which the most effective chitosan was determined as a substance [16]. When chitosan is dissolved in acetate solution, it loses $2 \%$ of its concentration [21], [27], [28].

The effectiveness of chitosan for improving the quality of drinking water by the removal of metal contents and microbial contaminants was confirmed. Increasing concentration of chitosan in drinking water led to decrease in turbidity, TDS, electrical conductivity and $\mathrm{pH}$. In addition, the chitosan had sedimented all the salts and improved water quality [21]. The relationship between chitosan concentration and each of turbidity, TDS, electrical conductivity and $\mathrm{pH}$ is linear. The determination coefficient ranged between 0.916 and 0.965 . Moreover, the effect of chitosan on the G- bacteria was higher than that on $\mathrm{G}+$ bacteria. The unique properties of chitosan made it an exciting and promising agent for using it in the purifying water [17].

Chitosan salts were purchased from "Medical Chitosan Egypt."

\section{RESUlTS}

Experimental work was executed in the National Research Center. Jar tester which is in the main laboratory of National Research Center, was used in bench-scale simulating processes of coagulation and flocculation to determine the different values of water turbidity. It consists of six flasks of total volume two liters per each flask as revealed clearly in Fig. 1.

A series of tests were carried out to determine the different values of turbidity, $\mathrm{pH}$, TDS, DO, salinity, conductivity, and temperature. Three jar tests were carried out for each coagulant, (alum, chitosan, and mix of alum/chitosan).

In the following tables, results obtained by conducting the previously mentioned experiments are summarized. In these tables, values of turbidity, conductivity, $\mathrm{pH}$, TDS, DO, salinity, conductivity, $\mathrm{BOD}_{5}, \mathrm{COD}, \mathrm{TOC}$, and temperature after filtration were recorded.

TABLE III: PH, TURBIDITy, REsiduAl Aluminum, AlgaE, BOD 5 , COD AND TOC USING ALUM ONLY, (CHITOSAN = ZERO)

\begin{tabular}{cccccccc}
$\begin{array}{c}\text { Alum } \\
\text { Dose } \\
\mathrm{mg} / \mathrm{L}\end{array}$ & $\mathrm{pH}$ & $\begin{array}{c}\text { Turbidity } \\
\text { NTU }\end{array}$ & $\begin{array}{c}\text { Residual } \\
\text { Aluminu } \\
\mathrm{m}\end{array}$ & $\begin{array}{c}\text { Algae } \\
\text { unit/m } \\
1\end{array}$ & $\begin{array}{c}\mathrm{COD} \\
\mathrm{ppm}\end{array}$ & $\begin{array}{c}\mathrm{BOD}_{5} \\
\mathrm{ppm}\end{array}$ & $\begin{array}{c}\text { TOC } \\
\mathrm{Ppm}\end{array}$ \\
\hline 19 & 7.41 & 1.8 & 0.21 & 240 & 10.6 & 7.6 & 3.49 \\
\hline 21 & 7.35 & 1.6 & 0.23 & 220 & 10.3 & 7.16 & 3.39 \\
\hline 23 & 7.31 & 1.4 & 0.25 & 200 & 10.15 & 6.9 & 3.34 \\
\hline 25 & 7.28 & 1.3 & 0.28 & 180 & 12.12 & 8.2 & 3.9 \\
\hline 27 & 7.27 & 1.6 & 0.30 & 150 & 12.72 & 8.9 & 4.19 \\
\hline 29 & 7.26 & 1.6 & 0.32 & 120 & 12.60 & 8.6 & 4.15 \\
\hline \hline
\end{tabular}

TABLE IV: PH, TURBIDITY, ALGAE, COD, BOD 5 AND TOC USING CHITOSAN ONLY, (ALUM = ZERO)

\begin{tabular}{ccccccc}
\hline $\begin{array}{c}\text { Chitosan } \\
\text { Doses } \\
\mathrm{mg} / \mathrm{L}\end{array}$ & $\mathrm{pH}$ & $\begin{array}{c}\text { Turbidity } \\
\text { NTU }\end{array}$ & $\begin{array}{c}\text { Algae } \\
\text { unit/ml }\end{array}$ & $\begin{array}{c}\text { COD } \\
\mathrm{ppm}\end{array}$ & $\begin{array}{c}\text { BOD }_{5} \\
\mathrm{ppm}\end{array}$ & $\begin{array}{c}\text { TOC } \\
\mathrm{ppm}\end{array}$ \\
\hline 2 & 6.92 & 2.7 & 230 & 12 & 10 & 3.96 \\
\hline 4 & 7.48 & 2 & 215 & 13 & 11 & 4.29 \\
\hline 6 & 7.19 & 2.15 & 200 & 13 & 11 & 4.29 \\
\hline 8 & 7 & 2 & 200 & 10 & 8 & 3.30 \\
\hline 10 & 6.89 & 2.11 & 180 & 14 & 12 & 4.62 \\
\hline 12 & 6.85 & 2.14 & 150 & 14 & 12 & 4.62 \\
\hline \hline
\end{tabular}


TABLE V: PH, Turbidity, Residual Aluminum, Algae, COD, BOD5 AND TOC Using Mixture OF ALUM/ChITOSAN

\begin{tabular}{ccccccccc}
\hline \hline $\begin{array}{c}\text { Chitosan Doses } \\
\mathrm{mg} / \mathrm{L}\end{array}$ & $\begin{array}{c}\text { Alum Doses } \\
\mathrm{mg} / \mathrm{L}\end{array}$ & $\mathrm{pH}$ & $\begin{array}{c}\text { Turbidity } \\
\text { NTU }\end{array}$ & $\begin{array}{c}\text { Residual } \\
\text { Aluminum }\end{array}$ & Algae unit/ml & $\begin{array}{c}\text { COD } \\
\mathrm{ppm}\end{array}$ & $\begin{array}{c}\text { BOD }_{5} \\
\text { Ppm }\end{array}$ & $\begin{array}{c}\text { TOC } \\
\text { Ppm }\end{array}$ \\
\hline 4 & 10 & 7.25 & 0.8 & 0.143 & 137 & 10 & 6.66 & 3.30 \\
\hline 4 & 20 & 7.96 & 0.8 & 0.201 & 63 & 11 & 6.67 & 3.63 \\
\hline 5 & 10 & 7.32 & 1.2 & 0.145 & 196 & 11 & 7.67 & 3.63 \\
\hline 5 & 15 & 7.46 & 0.85 & 0.166 & 148 & 7 & 3.15 & 3.95 \\
\hline 6 & 10 & 7.39 & 0.7 & 0.145 & 240 & 10 & 10 & 7.15 \\
\hline 6 & 5 & 7.07 & 2 & 0.033 & 165 & 10 & 3.30 \\
\hline \hline
\end{tabular}

\section{A. pH, Turbidity, and Residual Aluminum}

The results obtained from experiments using the jar tester were recorded in Tables III, IV, V, and Figs. 5-16. The $\mathrm{pH}$ of water affects the natural organic matter in water [15], [16]. The higher the $\mathrm{pH}$, the more organic matter is removed. The $\mathrm{pH}$ value decreases as the dose of alum, chitosan, and alum/chitosan increases. The best $\mathrm{pH}$ value was recorded when using 23,8 and $15 / 5 \mathrm{mg} / \mathrm{L}$ of alum, chitosan and alum/chitosan, respectively. Moreover, the TOC value was acceptable. To evaluate the effectiveness of the overall turbidity removal, the water was filtered after completion of the jar test by passing water over a sand filter. The combination of coagulation with optimum dose, sedimentation and sand filter reduced the turbidity of the treated water by $98.5,98.5$ and 99.5 percent when using alum, chitosan, or alum/chitosan, respectively.

It is clear from reports of the World Health Organization (WHO) over the past decade [5], that there is a problem about the relationship between aluminum residue in treated water and the spread of Alzheimer's disease. As a result, the research focused on the use of natural coagulants such as chitosan in water purification in an attempt to limit the spread of this disease [17].

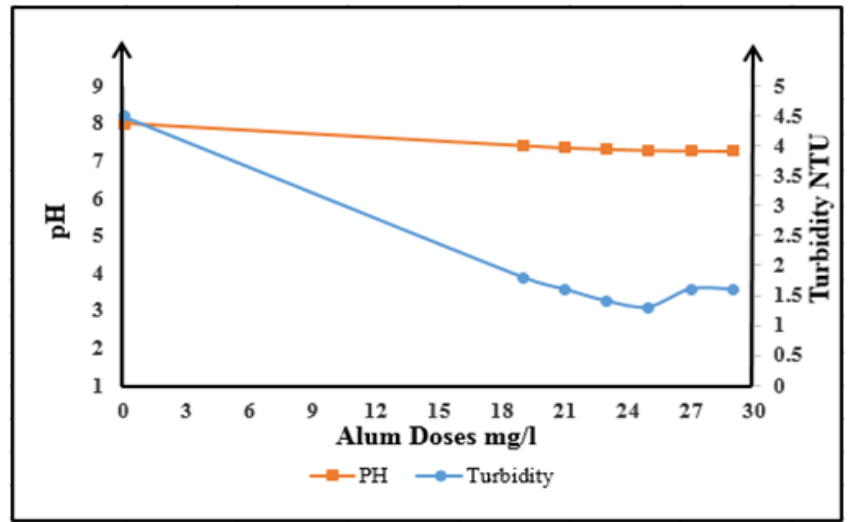

Fig. 5. Turbidity and $\mathrm{pH}$ in water versus alum doses.

Figs. 5, 6, 7, show the results we obtained for turbidity, $\mathrm{pH}$, and residual aluminum. Fig. 5 shows the use of alum and its effect on $\mathrm{pH}$ and turbidity. The results showed that the higher the alum dose, the lower the turbidity value to about 1.4. This value resulted when using a dose of $23 \mathrm{mg} / \mathrm{L}$ of alum, and also the $\mathrm{pH}$ decreases slightly to the value 7.31 using that dose of alum, i.e., $23 \mathrm{mg} / \mathrm{L}$ alum. Thus, we find that the best dose of alum to give the lowest turbidity is $23 \mathrm{mg} / \mathrm{L}$ and corresponding $\mathrm{pH}$ were recorded.

Fig. 6 shows the results we obtained when using chitosan as a coagulant and its effect on turbidity and $\mathrm{pH}$. The turbidity decreased with the increase in the dose of chitosan. The lowest value for turbidity was 2 when using a dose of $8 \mathrm{mg} / \mathrm{L}$ of chitosan, and the corresponding $\mathrm{pH}$ also decreased significantly. The $\mathrm{pH}$ value was 7 when using the dose of $8 \mathrm{mg} / \mathrm{L}$ of chitosan. Thus, from these results, the dose of $8 \mathrm{mg} / \mathrm{L}$ of chitosan as a coagulant is the optimum value recorded.

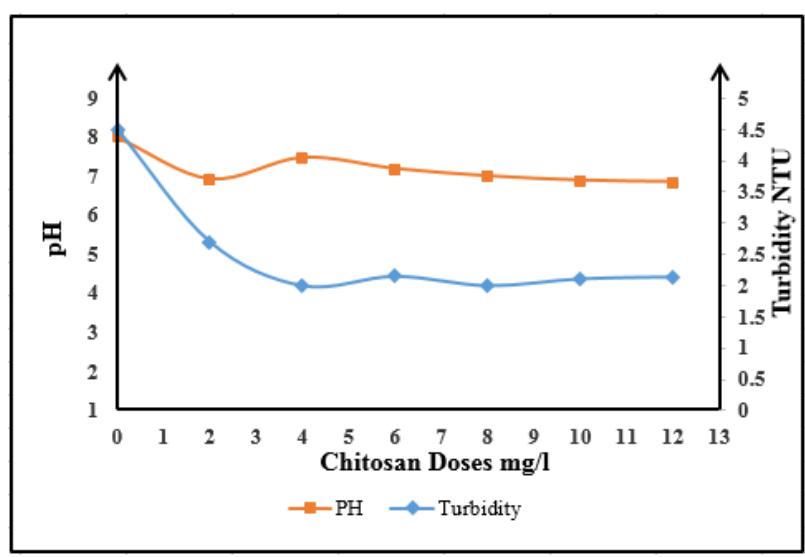

Fig. 6. Turbidity and $\mathrm{pH}$ in water versus chitosan doses.

Fig. 7 shows the value of the residual aluminum in the water after completion of the purification process when using alum in the plant as a coagulant, as the higher the dose of alum, the more aluminum remains in the water. Looking at the dose of $23 \mathrm{mg} / \mathrm{L}$ of alum, we find that the value of the residual aluminum is 0.25 , which is less than 0.5 , i.e., less than the permissible value in drinking water in Egypt. Thus, $23 \mathrm{mg} / \mathrm{L}$ is the dose of alum used in the purification plant.

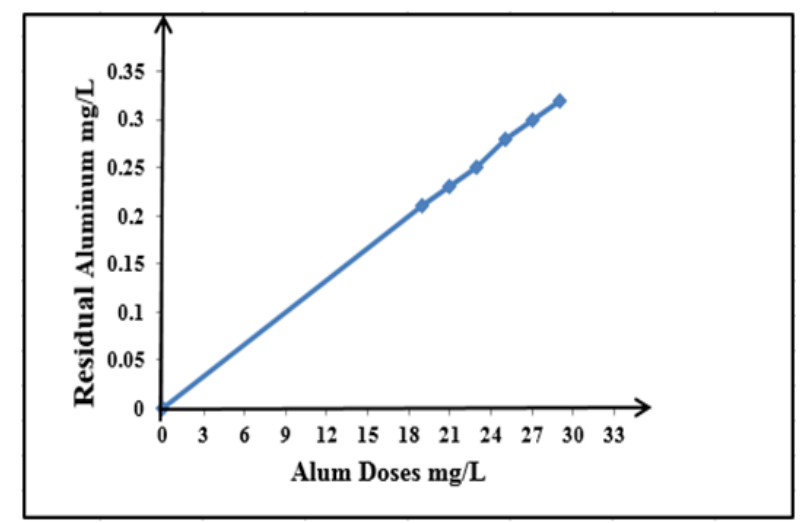

Fig. 7. Residual aluminum in water versus alum doses.

Figs. 8, 9, and 10 show the values of $\mathrm{pH}$, turbidity, and residual aluminum when using a mixture of alum/chitosan as a coagulant. Fig. 8 shows the $\mathrm{pH}$ values when using alum/chitosan together, where the $\mathrm{pH}$ value changes slightly 
as the doses increase. Fig. 9 shows the turbidity values when using different combination of doses of alum/chitosan coagulants.

The following doses resulted in acceptable results for turbidity and were recorded as best values obtained. The turbidity is 0.85 at a dose of $15 / 5$ of alum/chitosan, which is a good turbidity value, and the corresponding $\mathrm{pH}$ is 7.46 , which is an acceptable value. Therefore, the optimum doses that give the lowest turbidity is $15 / 5 \mathrm{mg} / \mathrm{L}$ of alum/chitosan.

Fig. 10 shows the values of residual aluminum in the water when using alum/chitosan together as a coagulant, as the remaining aluminum in water decreased when using alum/chitosan due to the use of lower doses of alum. This means that our aim succeeded by purifying water with less residual aluminum.

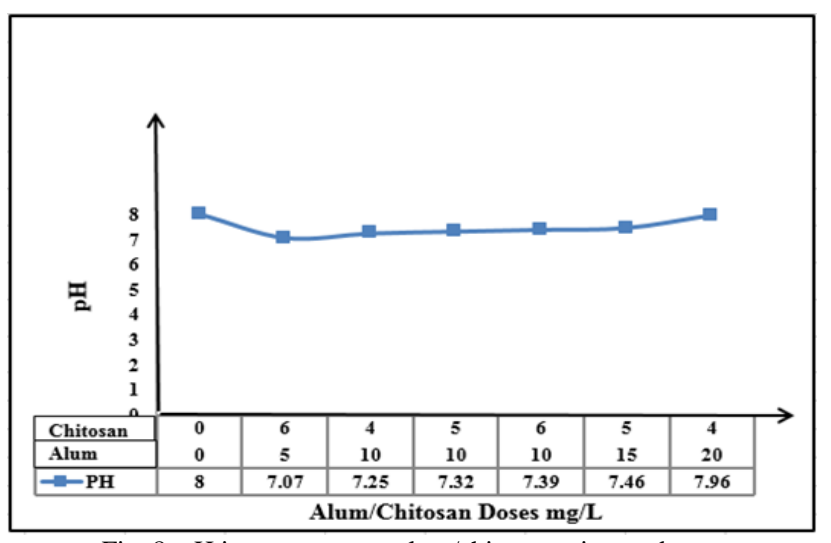

Fig. 8. pH in water versus alum/chitosan mixture doses.

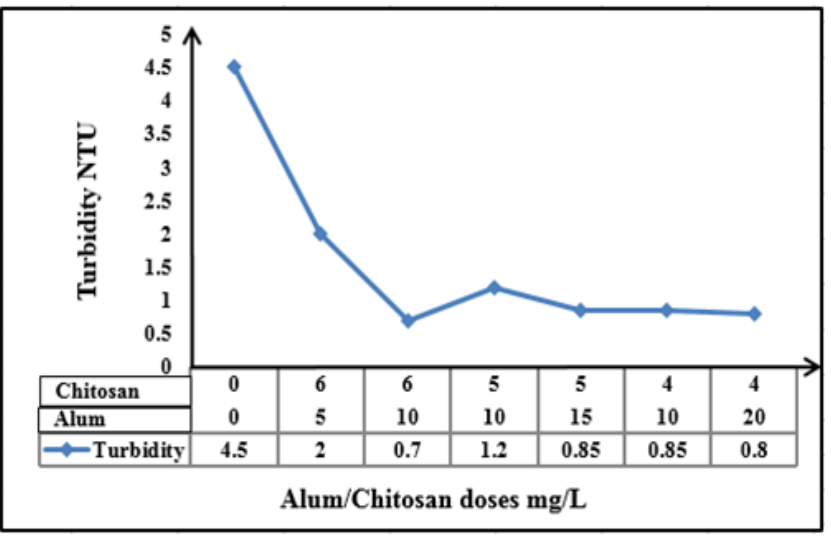

Fig. 9. Turbidity in water versus (alum/chitosan) doses.

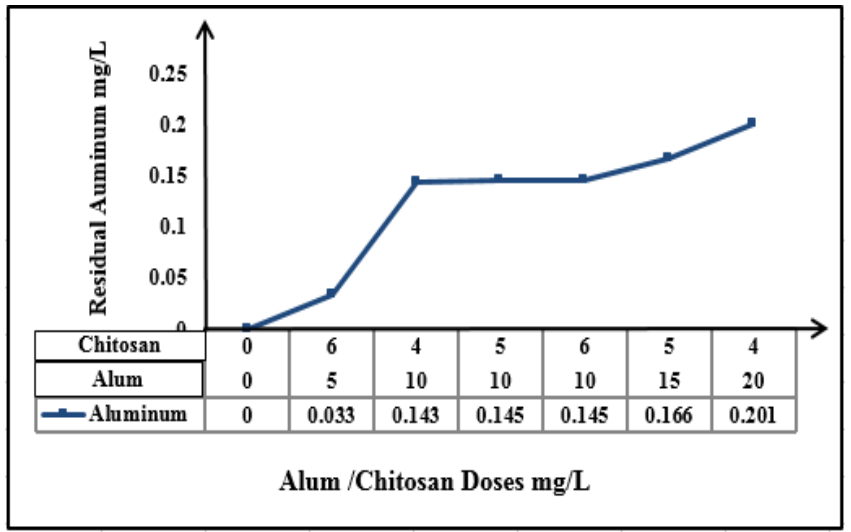

Fig. 10. Residual aluminum in water versus (alum/chitosan) doses.

\section{B. Removal of Algae}

Figs. 11,12, and 13 show the amount of algae present in the water after the purification process when using different materials such as alum, chitosan, and alum/chitosan together. Fig. 11 shows the amount of algae when using different doses of alum. The values demonstrate the amount of algae decreased when the dose of alum increased. The amount of $200 \mathrm{unit} / \mathrm{mL}$ of algae was recorded at the dose of $23 \mathrm{mg} / \mathrm{L}$ of alum in the purification plant. Fig. 12 shows the amount of algae when using different doses of chitosan. Using chitosan gave similar algae results that were obtained when using alum. The amount of algae decreased when using higher dose of chitosan. Fig. 13 shows the amount of algae when using a mixture of alum/chitosan together. The amount of algae decreased remarkably. In fact, the results were better than the results when using alum only or chitosan only. The amount of 148 unit/mL of algae was recorded when using the determined optimum dose $15 / 5 \mathrm{mg} / \mathrm{L}$ of alum/chitosan. When using the alum/chitosan mixture, it was found to be effective in coagulation, as the removal rate reached $93 \%$, at the optimum coagulant dosage and the corresponding $\mathrm{pH}$ value. It was also found that chitosan was more effective for removing algae from water with a $96 \%$ removal rate. From the previous results that were shown in the Figs. 11, 12, 13, when using a mixture of alum/chitosan as coagulant, the amount of algae decreased significantly. Therefore, it is preferable to mix alum with chitosan to get the lowest amount of algae in the water.

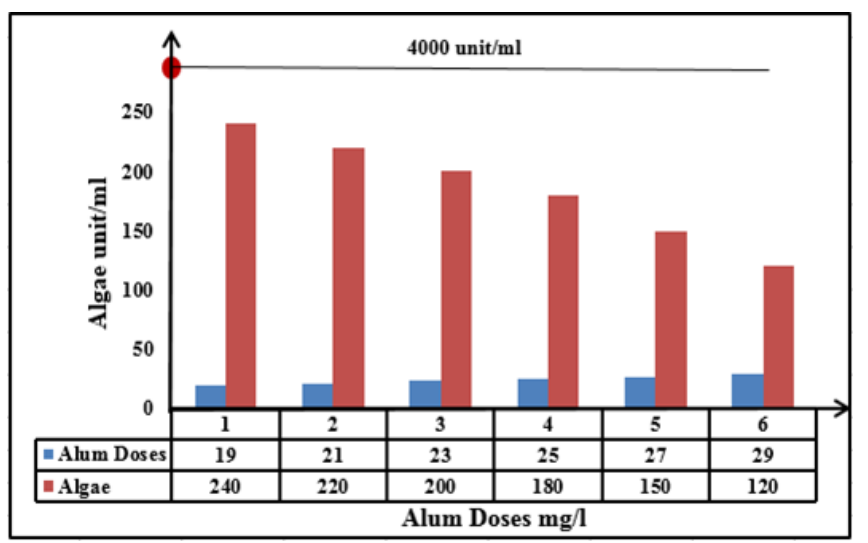

Fig. 11. Algae in water versus alum doses.

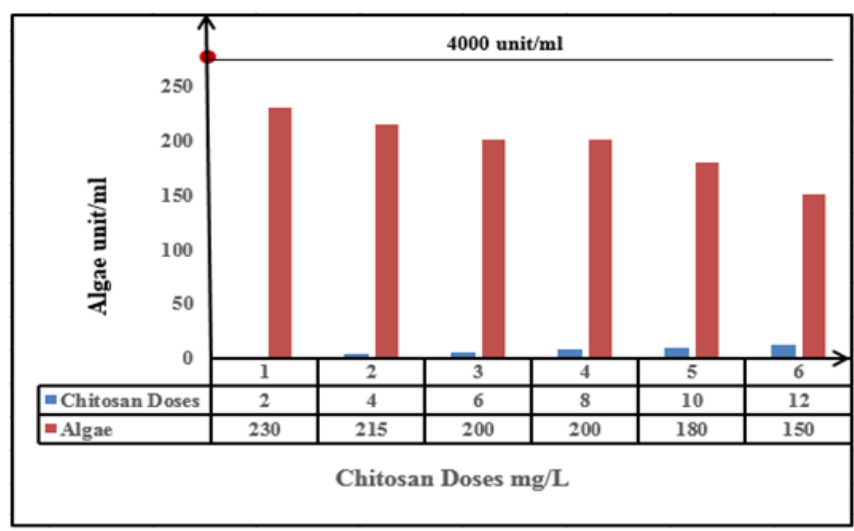

Fig. 12. Algae in water versus chitosan doses.

\section{NOM Removal}

Fig. 14, 15, and 16 show the values of the organic matter when using different coagulants in different doses for each coagulant: alum, chitosan, and alum/chitosan together. Organic matters are expressed by measuring $\mathrm{BOD}_{5}, \mathrm{COD}$, and TOC. 


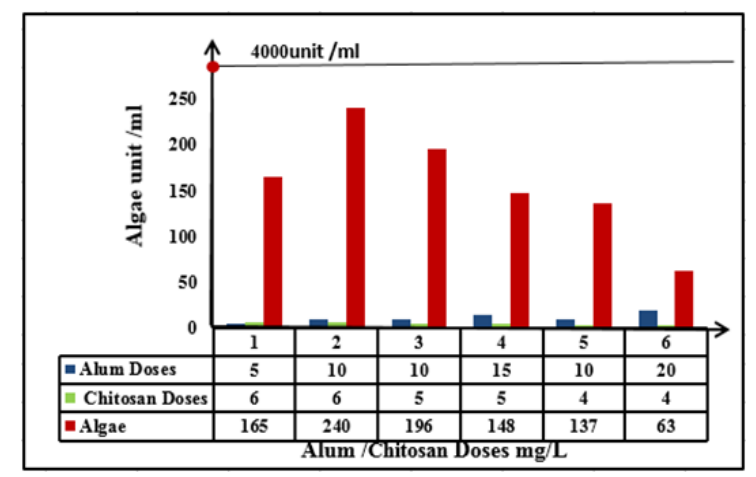

Fig. 13. Algae in water versus (alum/chitosan) doses.

Fig. 14 shows the results of $\mathrm{BOD}_{5}, \mathrm{COD}$, and TOC when using alum only as coagulant as it is taking place in the water purification plant. The values of $\mathrm{BOD}_{5}, \mathrm{COD}$, and TOC decrease as the dose of alum increases, so alum is effective in removing organic matter from water. The $\mathrm{pH}$ value ranged between 7.26-7.41 (average of 7.31). The $\mathrm{BOD}_{5}$ value decreased to 6.9. The COD value reached approximately $10.15 \mathrm{ppm}$ (44\% removal rate). The TOC value reached 3.34 ppm (removal rate up to $44 \%$ ).

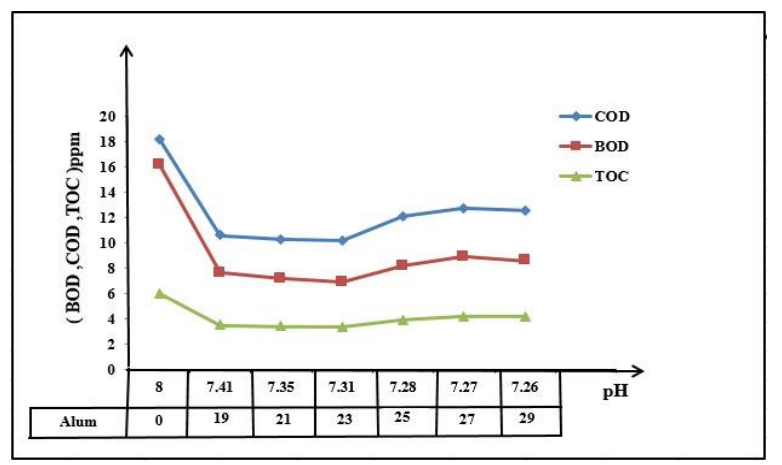

Fig. 14. Effect of $\mathrm{pH}$ on BOD5, COD, and TOC using alum.

Fig. 15 shows the results of $\mathrm{BOD}_{5}, \mathrm{COD}$, and TOC when using chitosan coagulant only. It was found when using the selected dose of $8 \mathrm{mg} / \mathrm{L}$ that the $\mathrm{pH}$ value ranged between 6.85-7.48 (average 7.06). The $\mathrm{BOD}_{5}$ value reached 8.0, and the COD value reached approximately $10.00 \mathrm{ppm}(45 \%$ removal rate). The TOC reached $3.3 \mathrm{ppm}$ (removal rate reached $45 \%$ ). Thus, from these results we find that using chitosan alone had no significant effect in removing natural organic matters as the results were almost the same as when using alum alone.

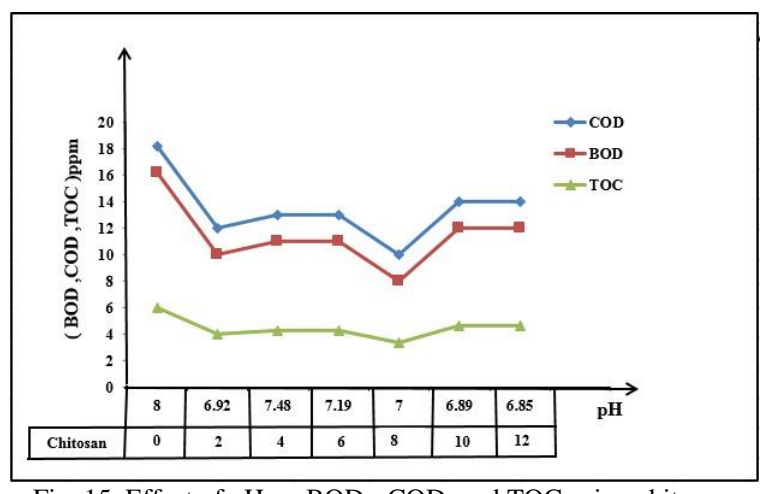

Fig. 15. Effect of $\mathrm{pH}$ on $\mathrm{BOD}_{5}, \mathrm{COD}$, and TOC using chitosan.

Fig. 16 shows the results of $\mathrm{BOD}_{5}, \mathrm{COD}$, and TOC when using alum/chitosan together. The mixture gave better results. It was found when using the selected dose $15 / 5 \mathrm{mg} / \mathrm{L}$ that the
$\mathrm{pH}$ value ranged between 7.07-7.96 (average 7.4). The value of $\mathrm{BOD}_{5}$ decreased to 5.0 and the value of $\mathrm{COD}$ reached approximately $7.00 \mathrm{ppm}$ (removal rate of $61.5 \%$ ), and TOC decreased to $2.31 \mathrm{ppm}$ (removal rate of $61.5 \%$ ). Therefore, we find that the effect of chitosan alone was not noticeable in removing natural organic matter, as almost the same results were obtained as using alum alone. However, the mixture gave good results as $\left(\mathrm{BOD}_{5}, \mathrm{COD}\right.$, TOC) were significantly reduced, and the results of a combination of alum/chitosan were the best.

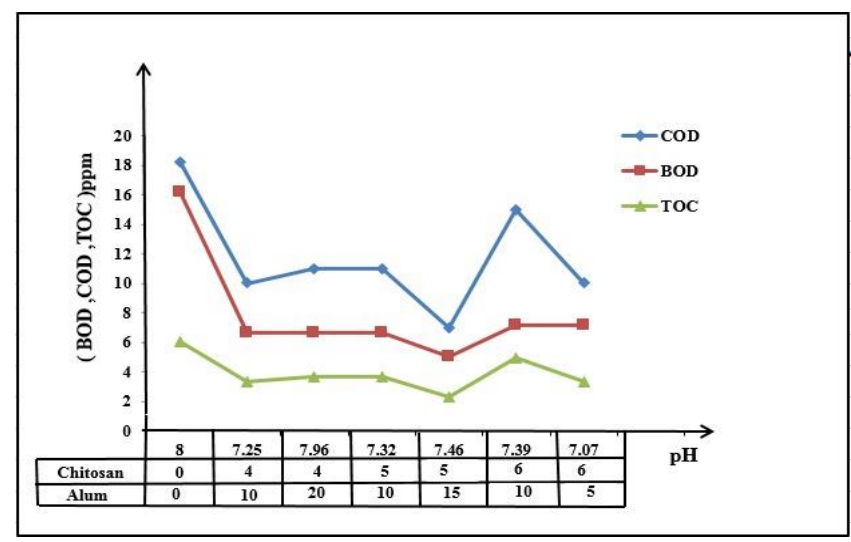

Fig. 16. Effect of $\mathrm{pH}$ on, $\mathrm{BOD}_{5}, \mathrm{COD}$, and $\mathrm{TOC}$ using (alum/chitosan).

\section{CONCLUSION}

The results of the research can be summarized as follows. The possibility of using a natural coagulant such as chitosan to purify the Nile River water and remove the natural organic matter effectively was confirmed. It was also confirmed that a dose of chitosan could be added to a dose of alum to reduce the percentage of alum used in purification plants and thus reduce the negative effects of using a high dose of alum, which leads to aluminum residuals in water. This in turn causes diseases such as Alzheimer's.

In addition, an experimental model was set up and experiments were carried out to investigate improving the removal efficacy of $\mathrm{NOM}, \mathrm{BOD}_{5}, \mathrm{COD}$, and TOC. Removal of $\mathrm{BOD}_{5}$ by chitosan was reduced as the $\mathrm{pH}$ was increased. Treated water COD levels were higher for chitosan than for alum. After using alum, chitosan, and alum/chitosan as coagulants, the turbidity of water became $1.4,2$, and 0.85 with removal efficiency $98.5,96.5$, and 99.5 percent respectively. The optimum value of $\mathrm{pH}$ was $7.31,7$, and 7.49 using coagulants, alum, chitosan, and alum/chitosan, respectively.

Removing algae using chitosan or alum/chitosan is better than using alum only. One of the advantages of using chitosan only or alum/chitosan is that it reduces the sedimentation time because the flocs formed are cohesive and large in size. Finally, the optimum coagulant dose used based on steady water turbidity was 8 , and $15 / 5 \mathrm{mg} / \mathrm{L}$ using chitosan and alum/chitosan as coagulants respectively. More future research is needed to start applying using environmentally friendly coagulants for water and wastewater treatment.

\section{ACKNOWLEDGMENT}

Great thanks and deep appreciation to Al-Azhar University 
and Port Said University their continuous support.

\section{CONFLICT OF INTEREST}

The authors declare no conflict of interest.

\section{AUTHOR CONTRIBUTIONS}

RSMAH, conducted the experiments and wrote the initial paper; AS, supervised, co-wrote the paper; HGIA, guided, reviewed and co-wrote the paper; MMHE, supervised, guided, co-wrote, and revised the paper; all authors approved the final version.

\section{REFERENCES}

[1] B. Eikebrokk and T. Saltnes, "NOM removal from drinking water by chitosan coagulation and filtration through lightweight expanded clay aggregate filters," Journal of Water Supply: Research and Technology-AQUA, IWA Publishing 51, vol. 6, pp. 323-332, Sep. 2002.

[2] S. A. Parsons, B. Jefferson, E. H. Goslan, P. R. Jarvis and D. A. Fearing, "Natural organic matter - The relationship between character and treatability," Water Science and Technology: Water Supply, IWA Publishing, vol. 4, pp. 43-48, 2004.

[3] B. Meyssami and A. B. Kasaeian, "Use of coagulants in treatment of olive oil wastewater model solutions by induced air flotation," Bioresource Technology Journal, Elsevier, vol. 96, pp. 303-307, 2005.

[4] B. B. Mamba, R. W. Krause, B. Matsebula, and J. Haarhoff, "Monitoring natural organic matter and disinfection by-products at different stages in two South African water treatment plants," Water SA, vol. 35, pp. 122-128, 2009.

[5] Guidelines for Drinking-Water Quality, 1st addendum to 3rd ed., World Health Organization, 2006, vol. 1.

[6] E. W. Dungumaro, "Socioeconomic differentials and availability of domestic water in Africa," Journal of Physics and Chemistry of the Earth, vol. 32, pp. 1141- 1147, 2007.

[7] F. Renaul, B. Sancey, P. M. Badot, and G. Crini, "Chitosan for coagulation/flocculation processes-an eco-friendly approach," European Polymer Journal, vol. 12, pp. 221-239, 2008.

[8] K. Fujisaki, "Experimental study on flocculation performance of chitosan-based flocculant using a novel jar tester," Journal of Civil Engineering and Environmental Sciences, Dec., 2018.

[9] L. Rizzo, A. Di Gennaro, G. Marialuisa, and V. Belgiorno, "Coagulation/chlorination of surface water: A comparison between chitosan and metal salts," Separation and Purification Technology, vol. 62, pp. 79-85, 2008.

[10] T. I. Nkambule, R. W. M. Krause, B. B. Mamba, and J. Haarhoff, "Characterization of natural organic matter (NOM) and its removal using cyclodextrin polyurethanes," Water SA, vol. 35, pp. 200-203, 2008.

[11] UNICEF. (2009). Soap, toilets and taps-A foundation for healthy children; How UNICEF supports water sanitation and hygiene. UNICEF. [Online] pp. 1-48. Available: https://unicef.at/fileadmin/media/Infos_und_Medien/Info-Material/W asser/Soap_toilets_and_taps.pdf

[12] A. Matilainen, M. Vepsäläinen, and M. Sillanpää, "Natural organic matter removal by coagulation during drinking water treatment: A review," Advances in Colloid and Interface Science, Elsevier, vol. 159, pp. 189-197, 2010.

[13] A. F. Ashry, K. Radwan, and M. I. G. A. Rashed, "The effect of pH control on turbidity and NOM removal in conventional water treatment," in Proc. Fifteenth International Water Technology Conference, IWTC 15, 2010, pp. 1-16.

[14] R. Lamsal, M. E. Walsh, and G. A. Gagnon, "Comparison of advanced oxidation processes for the removal of natural organic matter," Water Research Journal, vol. 45, pp. 3263-3269, 2011.

[15] C. D. Goss and B. Gorczyca, "Removal of natural organic matter fractions by two potable water treatment systems: Dual membrane filtration and conventional lime soda softening," IOWA Specialty Conference on Natural Organic Matter, 2011.

[16] A. Soros, Chitosan Coagulation for Household Water Treatment in Developing Countries, University of North Carolina at Chapel Hill Graduate School: Chapel Hill, NC, 2015.

[17] F. W. Pontius, "Chitosan as a drinking water treatment coagulant," American Journal of Civil Engineering, vol. 4, pp. 205-215, 2016.

[18] H. Chopra and G. Ruhi, "Eco friendly chitosan: an efficient material for water purification," The Pharma Innovation Journal, vol. 5, no. 1, pp. 92-95, 2016.
[19] L. S. Abebe, X. Chen, and M. D. Sobsey, "Chitosan coagulation to improve microbial and turbidity removal by ceramic water filtration for household drinking water treatment," International Journal of Environmental Research and Public Health, MDPI, vol. 13, pp. 1-12, 2016.

[20] A. Kangama, D. Zeng, X. Tian, and J. Fang, "Application of chitosan composite flocculant in tap water treatment," Hindawi Journal of Chemistry, vol. 2018, article ID 2768474, p. 9.

[21] A. J. Al-Manhel, A. R. S. Al-Hilphy, and A. K. Niamah, "Extraction of chitosan, characterization and its use for water purification," Journal of the Saudi Society of Agricultural Sciences, vol. 17. pp. 186-190,2018.

[22] M. Y. Saleh, S. El-Dosoky, and M. M. H. Elzahar, "Wastewater treatment by oxidation ponds in port said treatment plant (control of algae)," Port Said Engineering Research Journal, vol. 16, pp. 109-118, 2012.

[23] M. Y. Saleh, G. El Enany, M. M. H. Elzahar, and M. Z. Elshikhipy, "Industrial wastewater treatment using high rate activated sludge and alum additive," International Journal of Environmental Science and Development, Singapore, vol. 5, no. 6, Dec 2014.

[24] M. Y. Saleh, G. El Enany, M. M. H. Elzahar, M. Z. Elshikhipy, and R. Hamouda, "Removal of lead in high rate activated sludge system," World Academy of Science, Engineering and Technology, vol. 8, Mar. 2014.

[25] M. Y. Saleh, G. El Enany, M. M. H. Elzahar, and M. Z. Elshikhipy, "Use of alum for removal of total dissolved solids and total iron in high rate activated sludge system," International Journal of Environmental Science and Development, vol. 2, no. 3, pp. 1-12, Mar. 2014.

[26] J. Salvé, B. Grégoire, L. Imbert, F. Hubert, N. K. V. Leitner, and M. Leloup, "Design of hybrid chitosan-montmorillonite materials for water treatment: Study of the performance and stability," Chemical Engineering Journal Advances, vol. 6, 2021.

[27] A. Croitoru, A. Ficai, D. Ficai, R. Trusca, G. Dolete, E. Andronescu, and S. C. Turculet, "Chitosan/Graphene oxide nanocomposite membranes as adsorbents with applications in water purification," Membranes, MDPI, Materials, vol. 13, no. 7, p. 1687, 2020.

[28] A. Spoiala, C. Ilie, D. Ficai, A. Ficai, and E. Andronescu, "Chitosan-based nanocomposite polymeric membranes for water purification - A review," Membranes, MDPI, Materials, vol. 14, p. 2091, 2021 .

Copyright (C) 2022 by the authors. This is an open access article distributed under the Creative Commons Attribution License which permits unrestricted use, distribution, and reproduction in any medium, provided the original work is properly cited (CC BY 4.0).

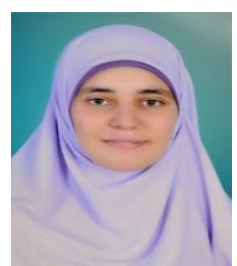

Rania S. M. A. Hamdon was born in El-Behera, Egypt, 1990. She is a teaching assistant, specializing in environmental engineering with an emphasis on sanitary and environmental hydraulics. She obtained her B. Sc. in civil engineering, Giza Engineering Institute, Giza, Egypt, 2013, Department of Civil Engineering. Her research interests include water, wastewater treatment, and sludge disposal and

management.

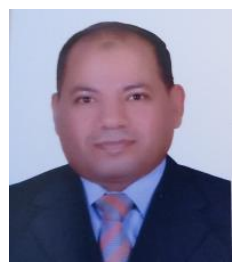

Ahmed Salem was born on 1971 at Sohag, Egypt. He is currently an assistant professor at the Department of Civil Engineering, Al-Azhar University, Cairo, Egypt His specialization is in environmental engineering with an emphasis on sanitary engineering. In 2008, he has got a full Egyptian Government Scholarship to study the doctoral degree (Ph.D.) in Germany and he completed his Ph.D. from the Bremen University, Germany in April 2012. He obtained his M.Sc. in Sanitary Engineering (2001), Al-Azhar University, Cairo, Egypt. He got his B. Sc. in Civil Engineering Department (1994). He was demonstrator and assistant lecturer, Civil Engineering Department, Faculty of Engineering, Al-Azhar University, Cairo-Egypt, January 1996 - January 2008. His main area of specialization is modeling of hydraulic behavior of inclined plate settlers by using Computational fluid dynamics (CFD), and Water/Wastewater treatment.

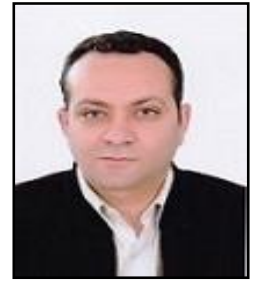

Hany G. I. Ahmed was born on 1977 at Daqahliya, Egypt. He is currently an Associate Professor at the Department of Civil Engineering, Al-Azhar University, Cairo, Egypt. His specialization is in Hydraulics. In 2008, he has got a full Egyptian Government Scholarship to study the doctoral degree (Ph.D.) in Germany. He completed his Ph.D. from University of Wuppertal, Germany in December 2011. (Research PhD topic: Wave 
interaction with vertical slotted wall as a permeable breakwater). $\mathrm{He}$ obtained his M.Sc. in Irrigation and Hydraulic dept. (2005), (Research M.Sc. topic: Factors affecting the flow through irrigation distributors), Al-Azhar University, Cairo, Egypt. He got his B. Sc. in Civil Engineering Department (2000). He was demonstrator and assistant lecturer, Civil Engineering Department, Faculty of Engineering, Al-Azhar University, Cairo-Egypt, January 2002-October 2007. His research interests include hydraulics, water resources, and water management.

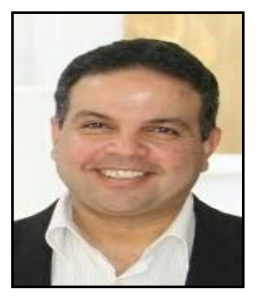

Medhat M. H. EIZahar was born in Port Said, Egypt, 1969. $\mathrm{He}$ is an associate professor specializing in environmental engineering with an emphasis on sanitary and environmental hydraulics. $\mathrm{He}$ obtained his $\mathrm{Ph}$. D. in sanitary and environmental hydraulics, (2003), completed via a cooperative research program between Suez Canal University, Egypt, and Kyushu Institute of Technology, Kitakyushu, Japan. He got his M.Sc. in environmental hydraulics (1997), Suez Canal University, Port Said, Egypt. He obtained his B. Sc. in Civil Engineering Department (1992), Suez Canal University, Port Said, Egypt. Visiting Researcher, Kyushu Institute of Technology, Kitakyushu, Japan, 08/1999-02/2002 (Research PhD topic based on developing innovative research on wastewater treatment). Teaching assistant, Suez Canal University, Port Said, Egypt, 1995-2003. Departmen of Civil Engineering, Port Said University, Port Said, Egypt. His research interests include water wastewater treatment, and sludge disposal and management. 